\title{
Feed Intake, Live Weight Gain and Carcass Yield Characteristics of Intact Hararghe Highland Male Goats Fed on Different Hay to Concentrate Ratios
}

\author{
Asnakew Awuk and Berhan Tamir* \\ Department of Animal Sciences, Haramaya University, P O Box 40 Haramaya, Ethiopia
}

\begin{abstract}
Feed intake, live weight gain and carcass yield characteristics were studied using twenty-five yearling intact Hararghe highland male goats $(17.6 \pm 0.11 \mathrm{~kg}$ body weight) fed diets containing different hay to concentrate ratios, viz., 100:0, 80:20, 70:30, 60:40 and 50:50\% for T1, T2, T3, T4 and T5, respectively, in a randomized complete block design experiment with five animals per treatment that lasted for 90 days. The amount of CP supplied was $3.73,10.15,13.36,16.57$ and $19.79 \%$ per $\mathrm{kg} \mathrm{DM}$ and the ME (MJ/kg DM) was $6.64,7.51,7.95,8.38$ and 8.82 for the respective treatments. Dry matter and nutrient intakes were measured daily, while live weight gain and feed conversion efficiency were recorded at the weekly interval. At the end of the feeding trial, all goats from each treatment were fasted for $12 \mathrm{~h}$ and slaughtered after taking the slaughter weight of each goat. Measurements were also taken on empty body weight, hot carcass weight, dressing percentage (DP) and rib eye muscle area. Concentrate supplementation of goats resulted in high (P< $0.05)$ dry matter, crude protein and metabolizable energy intake, which was reflected in increased $(\mathrm{P}<0.05)$ average daily weight gain (ADWG) and feed conversion efficiency (FCE). The empty body weight, hot carcass weight, DP and rib eye muscle area were higher $(\mathrm{P}<0.05)$ for concentrate supplemented groups compared to those fed on hay alone. Goats on equal hay to concentrate ratio (T5) had higher empty body weight, hot carcass weight and rib eye muscle area when compared to those on T2 and T3. Different proportions of hay to concentrate did not affect the DP, but carcasses dressed from goats offered with concentrate feeds had higher $(\mathrm{P}<0.05)$ percentages of lean and boneless meat, and lean: bone and lean + fat: bone ratios, but lower percentage of bone than the carcasses from goats fed hay alone. The percentage of boneless meat was similar between goats on T2, T4 and T5, while the percentage of total edible offal components was similar between supplemented and un-supplemented groups. The proportion of the gut content and total non-edible offal components decreased with the increasing concentrate level, while the percentage of the total saleable components increased. Correlation and regression analysis revealed a positive and significant $(\mathrm{P}<0.01)$ relationship between dry matter intake $(r=0.67)$, slaughter weight $(r=0.89)$, hot carcass weight $(r=0.90)$, dressing percentage $(r=0.70)$, lean meat $(r=0.95)$ and rib-eye muscle area $(r=$ $0.92)$ with the level of concentrate supplementation. However, there was a non-significant $(P>0.05)$ weak negative correlation $(\mathrm{r}=-0.16)$ between ADWG and the level of concentrate supplementation. Considering ADWG, FCE, DP and percentage of boneless meat, the diet with $20 \%$ concentrate level could be recommended for optimum live weight gain, feed conversion efficiency and carcass yield characteristics of goats.
\end{abstract}

Keywords: Body Weight Gain; Carcass Yield; Feed Intake; Hararghe Highland Goats; Hay to Concentrate Ratio

\section{Introduction}

In Ethiopia, the population of goats is estimated to be 13 million, which are distributed across varied agroecological zones (CSA, 2003). Goats are closely associated with poor households providing immediate cash income and animal protein source being widely consumed among the people owing to their comparative small size. In spite of the wide distribution of goats and acceptance of the goat meat, the level of on-farm productivity of goats in the smallholder production systems is very low with the average dressed carcass output of $8 \mathrm{~kg}$ per goat (FAO, 2001). The productivity of goats is constrained by a number of factors, among which seasonal fluctuations in quantity and quality of feeds is the major one (Aschalew et al., 2000). On the other hand, the demand for goat meat is rising due to population growth, urbanization andrisingincome (FAO, 1997), leading to frequent slaughtering of young and thinner animals. Meat production capacity of goats is higher when they are one to two years of age and slaughtering of goats at heavier weights could possibly be advantageous for producers by providing greater profits from meat sales, and for consumers by supplying matured meat with improved quality (Devendra and Burns, 1983; Manfredini et al., 1988). The declining demand for animal fat and the increased emphasis on red meat production also suggests a greater need for goat meat production (Ruvuna et al., 1992).

Improvement in the plane of nutrition by supplementation of concentrates or grains to fibrous feeds can promote faster daily live weight gain and thus enable the attainment of acceptable market weight at earlier age (Parthasarathy et al., 1984). Supplementation with cereal grains could usually put 
goat production in direct competition with human being. Instead, utilization of locally available agroindustrial by-products as supplementary feeds may be a feasible feeding system for stall-feeding of goats for commercial production and at the same time converting non-edible agro-industrial by-products into highly nutritious animal foods. This system would create possibilities of getting alternative feeds to ensure that the animals take complementary rather than a competitive part with man. Among the various agroindustrial by-products wheat bran, groundnut (Arachis hypogeae) cake and brewer's dried grain are believed to be important supplements for goats and are relatively cheap and readily available for urban and peri-urban goat producers living in the vicinity of oil extracting, flour milling and brewing plants.

Thus, this study was undertaken with the objectives of assessing the effects of feeding different levels of hay to concentrate ratios on the feed intake, live weight gain and carcass yield characteristics of yearling intact Hararghe Highland male goats.

\section{Materials and Methods}

\subsection{Animals, Experimental Design and Treatments}

The experiment was conducted at Haramaya University Dairy Goat Farm, located at an altitude of 1980 m.a.s.1, $9^{\circ} 24^{\prime} \mathrm{N}$ latitude and $41^{\circ} 5^{\prime} \mathrm{E}$ longitude (AUA, 1996). Twenty-five yearling intact Hararghe Highland male goats $(17.6 \pm 0.11 \mathrm{~kg}$ initial body weight) were used. The goats were drenched and sprayed against internal and external parasites, respectively. Animals were penned individually and allowed to adapt to the pens and feeds for 14 days prior to the commencement of the feeding trial, which lasted for 90 days. Goats were blocked into five groups based on their initial body weights and randomly assigned to one of the 5 feeding treatments, T1, T2, T3, T4 and T5, in randomized complete block design (RCBD).

\subsection{Feeds and Feeding}

The basal feed used in this experiment was grass hay dominated by Hyparrhenia rufa species, while the concentrate was composed of mixtures of $45 \%$ groundnut cake, $35 \%$ brewer's dried grain and $20 \%$ wheat bran on dry matter basis. The daily feed allowance was offered at the rate of $3.8 \%$ of the body weight on DM basis and the treatments consisted of feeding of $100 \%$ hay to $0 \%$ concentrate (T1), $80 \%$ hay to $20 \%$ concentrate (T2), $70 \%$ hay to $30 \%$ concentrate (T3), $60 \%$ hay to $40 \%$ concentrate (T4) and $50 \%$ hay to $50 \%$ concentrate (T5). The quantities of offers of hay and concentrate feeds amounted to $674+0,539+132$, $472+199,404+266$ and $337+337$ g DM, whereas the $\mathrm{CP}$ contents were $37.3,101.5,133.6,165.7$ and
$197.9 \mathrm{~g} / \mathrm{kg} \mathrm{DM}$ and the ME contents were 6.64, 7.51, $7.95,8.38,8.82 \mathrm{MJ} / \mathrm{kg} \mathrm{DM}$ for the respective treatments.

Except for the control treatment, the CP level in concentrate supplemented groups was maintained to meet the nitrogen requirements of growing goats (ARC,1980). The daily amounts of hay and concentrate feeds were offered in separate troughs. The concentrate feed was offered once at $0800 \mathrm{~h}$ daily, whereas the hay was offered twice daily at 0800 and $1400 \mathrm{~h}$. The amounts of feed offered and refused were recorded daily for each animal. Experimental goats had free access to clean water and mineral licks at all times.

Samples of feed offered were collected daily per treatment and samples of feed refused were taken daily for each animal. Sub-samples of feed offered and refused were then dried at $60^{\circ} \mathrm{C}$ to constant weight, ground using a laboratory mill (Willey Mill, UK) to pass through a $1 \mathrm{~mm}$ mesh screen and pooled over the experimental period pending analysis.

Daily dry matter intake (DMI) was determined as a difference between the feed offered and refused. Animals were weighed weekly after overnight fasting using suspended scales with a sensitivity of $200 \mathrm{~g}$. Initial and final live weights of animals were determined by weighing of animals at the start and end of the trials, respectively. The body weight gain was computed as a difference between the final and initial body weights divided by the number of experimental days.

\subsection{Carcass Yield Characteristics}

Goats in each treatment were fasted for about 12 hours and slaughtered immediately after taking the slaughter weight. After slaughter, the carcass was dressed as described by Ashbrook (1955). The blood was drained into bucket and weighed. After skinning and decapitation, external offal components (head and horn, skin and feet) and internal offal components (heart, trachea, lungs, liver, spleen, gall bladder, testis, penis, rectum, kidneys, omental fat, intestinal fat and kidney fat, pancreas and different parts of the gastrointestinal tract with contents) were separated from the carcass. The weight of the dressed carcass was taken as empty body weight, and the different parts of the gastrointestinal tract (rumen, reticulum, omasum, abomasum, small intestine and large intestine) were weighed with and without the contents. The weights of edible offal components (including liver, heart, kidneys, lungs, small intestine, reticulo-rumen, omasoabomasum, omental fat, intestinal fat, kidney fat, blood and testicles) and non-edible offal components (spleen, head and horn, penis, gall bladder, gut content, pancreas, feet, rectum, tail, skin and large intestine) 
were also recorded. The carcass was cut longitudinally into two halves along the spine and weighed separately. The right half was weighed immediately as hot carcass weight, whereas the left half was chilled overnight at 4 ${ }^{\circ} \mathrm{C}$ and the chilled carcass was weighed and then separated into fore- and hindquarters which in turn were jointed into main tissue components, i.e. bone, muscle (lean) and fat. Both the right and left halves were cut between the $12^{\text {th }}$ and $13^{\text {th }}$ ribs perpendicular to the backbone as described by Ashbrook (1955) to measure the cross sectional area of the longissimus dorsi (rib-eye muscle). The cross section of the rib-eye muscle was traced onto a paper and the area of the squares that fell within the traced area was then counted. For the portions of the rib-eye muscle area that were less than a whole square, an estimated fraction value of the square was assigned. The average of the two (the right and left halves) was taken as the rib-eye muscle area.

\subsection{Laboratory Analysis}

Laboratory analysis of the experimental feeds was conducted at the International Livestock Research Institute (ILRI), Addis Ababa. Samples of feed offers and refusals were analyzed for dry matter (DM), ash, organic matter (OM), ether extract $(\mathrm{EE})$ and nitrogen (N) according to procedures of AOAC (1990). Crude protein (CP) was estimated as $\mathrm{N} \times$ 6.25. Neutral detergent fiber (NDF), acid detergent fiber (ADF) and acid detergent lignin (ADL) were analyzed according to Van Soest et al. (1991). Gas production (GP) was determined following the procedure of Menke and Steingass (1988). Metabolizable energy (ME) was computed by prediction equations using the gas production technique (Menke and Steingass, 1988) as:

$\mathrm{ME}=2.20+0.1357 \mathrm{GP}+0.0057 \mathrm{CP}+0.0002859$

$(\mathrm{EE})^{2}$ and $\mathrm{ME}=1.06+0.157 \mathrm{GP}+0.0084 \mathrm{CP}+$

0.0224EE - 0.0081TA, for hay and concentrate feeds, respectively.

Where $\mathrm{ME}=$ Metabolizable energy $(\mathrm{MJ} / \mathrm{kg} \mathrm{DM})$, GP $=$ gas production $(\mathrm{ml}), \mathrm{CP}=$ crude protein, $\mathrm{EE}=$ ether extract, $\mathrm{TA}=$ total ash.

\subsection{Statistical Analysis}

Data were subjected to analysis of variance using the general linear model (GLM) procedure SAS (1998) software. Treatment means were separated by least significant difference (LSD). The relationship between the response variables and the level of concentrate supplementation was analyzed using correlation and regression analysis.

\section{Results and Discussion}

3.1. Feed and Nutrients Intake, and Body Weight Gain

The control diet was characterized by its low $\mathrm{CP}, \mathrm{EE}$, ME and GP, and high ash, NDF and ADF contents (Table 1). The CP and ME contents of the control diet were too low to meet the maintenance requirements of growing goats.

Table 1. Chemical composition, metabolizable energy content and gas production of the experimental feeds

\begin{tabular}{lrrrrr}
\hline Chemical components & \multicolumn{3}{c}{ Treatments } & \multicolumn{1}{c}{ T4 } \\
\cline { 2 - 5 } & \multicolumn{1}{c}{ T1 } & \multicolumn{1}{c}{ T2 } & \multicolumn{1}{c}{ T3 } & 91.57 \\
\hline DM (\%) & 91.77 & 91.69 & 91.65 & 91.61 & 6.64 \\
Ash (\% DM) & 8.62 & 7.83 & 7.43 & 7.03 & 93.37 \\
OM (\% DM) & 91.38 & 92.17 & 92.57 & 92.97 & 4.00 \\
EE (\% DM) & 1.23 & 2.34 & 2.89 & 3.44 & 19.79 \\
CP (\% DM) & 3.73 & 10.15 & 13.36 & 16.57 & 59.77 \\
NDF (\% DM) & 70.67 & 66.31 & 64.13 & 61.95 & 33.96 \\
ADF (\% DM) & 48.32 & 42.58 & 39.70 & 36.83 & 4.79 \\
ADL (\% DM) & 4.69 & 4.73 & 4.75 & 4.77 & 8.82 \\
ME (MJ/kg DM) & 6.64 & 7.51 & 7.95 & 8.38 & 47.80 \\
GP (ml) & 16.36 & 40.21 & 42.76 & 45.25 & \\
\hline
\end{tabular}

$D M$, dry matter; OM, organic matter; EE, ether extract; $N D F$, neutral detergent fiber; $A D F$, acid detergent fiber; ADL, acid detergent lignin; $C P$, crude protein; ME, metabolizable energy; GP, gas production.

On the other hand, concentrate supplementation increased the amounts of CP,EE,ME,GP, and reduced the contents of ash, NDF and ADF. The $\mathrm{CP}$ and $\mathrm{ME}$ contents were within the recommended ranges of $\mathrm{CP}$ and $\mathrm{ME}$ requirements of growing of tropical goats (ARC, 1980).

The mean daily DMI of goats was significantly different $(\mathrm{P}<0.05)$ among treatments (Table 2$)$. 
Table 2. Dry matter and nutrient intakes and body weight change of yearling intact Hararghe Highland male goats fed with different hay to concentrate ratios

\begin{tabular}{|c|c|c|c|c|c|c|}
\hline \multirow[t]{2}{*}{ Parameters } & \multicolumn{5}{|c|}{ Treatment } & \multirow[t]{2}{*}{ SEM } \\
\hline & T1 & T2 & T3 & T4 & T5 & \\
\hline Total DM intake $(\mathrm{g} / \mathrm{d})$ & $478.60^{\mathrm{b}}$ & $519.60^{b}$ & $492.10^{b}$ & $522.60^{\mathrm{ab}}$ & $580.00^{\mathrm{a}}$ & 20.054 \\
\hline Total DM intake, $\mathrm{g} / \mathrm{kg}$ MBW & $55.59^{\mathrm{a}}$ & $56.49^{\mathrm{a}}$ & $54.40^{\mathrm{a}}$ & $56.28^{\mathrm{a}}$ & $60.85^{\mathrm{a}}$ & 1.677 \\
\hline Total DM intake, \% BW & $2.71^{\mathrm{a}}$ & $2.70^{\mathrm{a}}$ & $2.61^{\mathrm{a}}$ & $2.68^{\mathrm{a}}$ & $2.87^{\mathrm{a}}$ & 0.075 \\
\hline \multicolumn{7}{|l|}{ Nutrient intake } \\
\hline NDF intake $(\mathrm{g} / \mathrm{d})$ & $338.21^{\mathrm{a}}$ & $338.42^{\mathrm{a}}$ & $304.37^{\mathrm{a}}$ & $311.07^{\mathrm{a}}$ & $337.46^{\mathrm{a}}$ & 14.140 \\
\hline ADF intake $(\mathrm{g} / \mathrm{d})$ & $231.30^{\mathrm{a}}$ & $213.20^{\mathrm{ab}}$ & $180.60^{\mathrm{c}}$ & $176.00^{\mathrm{c}}$ & $185.00^{\mathrm{bc}}$ & 9.671 \\
\hline $\mathrm{CP}$ intake $(\mathrm{g} / \mathrm{d})$ & $17.85^{\mathrm{e}}$ & $61.75^{\mathrm{d}}$ & $82.32^{\mathrm{c}}$ & $104.90^{\mathrm{b}}$ & $128.10^{\mathrm{a}}$ & 0.078 \\
\hline Energy intake (MJ ME/d) & $3.18^{\mathrm{d}}$ & $4.02^{c}$ & $4.14^{\mathrm{bc}}$ & $4.63^{\mathrm{b}}$ & $5.30^{\mathrm{a}}$ & 0.133 \\
\hline Initial BW $(\mathrm{kg})$ & $17.70^{\mathrm{a}}$ & $17.70^{\mathrm{a}}$ & $17.65^{\mathrm{a}}$ & $17.55^{\mathrm{a}}$ & $17.40^{\mathrm{a}}$ & 0.110 \\
\hline Final BW (kg) & $17.65^{\mathrm{c}}$ & $20.80^{\mathrm{b}}$ & $20.20^{\mathrm{b}}$ & $21.60^{\mathrm{ab}}$ & $23.10^{\mathrm{a}}$ & 0.620 \\
\hline Average daily gain/loss (g/d) & $-0.56^{\mathrm{c}}$ & $34.44^{\mathrm{b}}$ & $28.33^{\mathrm{b}}$ & $45.00^{\mathrm{ab}}$ & $63.33^{\mathrm{a}}$ & 6.498 \\
\hline FCE (g feed DMI/g BW gain) & $137.40^{\mathrm{b}}$ & $15.67^{\mathrm{a}}$ & $19.79^{\mathrm{a}}$ & $13.75^{\mathrm{a}}$ & $9.55^{\mathrm{a}}$ & 9.660 \\
\hline
\end{tabular}

The DMI as percentage of body weight in all of the groups was within the range of the reported values of 1.7 to $4.8 \%$ of body weight for various breeds of goats in the tropics (Devendra and Burns, 1983). However, the DMI per kg metabolic BW of goats in T2, T3, T4 and T5 (Table 2) was higher than the value $(54.2 \mathrm{~g} / \mathrm{kg}$ MBW) reported by Pralomkarn et al. (1995) for Thai native male goats fed on concentrate-based diets. Getahun (2001) reported slightly higher DMI of 68.03 and $64.66 \mathrm{~g} / \mathrm{kg}$ metabolic $\mathrm{BW}$, under intensive management system for local Somali and Mid-Rift Valley goats, respectively. Similar amounts of DMI between goats fed with high and low energy diets had been also reported (Shahjalal et al., 1992). Correlation and regression analysis indicated a positive and significant $(\mathrm{P}<0.01)$ relationship between DMI and the level of concentrate supplementation $(r=0.67)$.

No significant differences were observed in NDF intake, while the ADF intake of goats in T1 was found to be higher $(\mathrm{P}<0.05)$ than the intakes recorded in T3, T4 and T5. McDonald et al. (2002) reported that NDF and ADF contents feeds reflect their voluntary intake and digestibility. There was a significantly $(\mathrm{P}<0.01)$ increasing trend in $\mathrm{CP}$ and energy intakes with the increase in the concentrate level, the highest being in $\mathrm{T} 5$ and the lowest in T1 $(\mathrm{P}<0.01)$. Goats supplemented with $20,30,40$ and $50 \%$ concentrate levels were receiving CP levels of 2.97, 4.08, 4.88 and 5.55 per $\mathrm{kg}$ of metabolic body weight and per day, respectively, which were above their maintenance requirement. While the goats fed with hay only were receiving $\mathrm{CP}$ level of 1.01 per $\mathrm{kg}$ of metabolic body weight and per day, which was not meeting even their maintenance requirement. Also the energy intake of T1 was below the maintenance requirement as compared to goats in T3, T4 and T5. Devendra and Burns (1983) reported that the protein requirement of goats from tropical Africa averages 2.20 DCP per kg of metabolic body weight and per day.

Concentrate supplementation promoted daily live weight gain while feeding hay only resulted in body weight loss (Table 2). The loss in body weight of goats in $\mathrm{T} 1$ of the current study might be attributed to the higher ADF and lower CP and energy intakes. This is in agreement to the explanation made by McDonald et al. (2002) in that rumination and fermentation are slow processes, and fibrous feeds may have to spend a long time in the digestive tract for their digestible components to be extracted, posing difficulty to ruminants in processing bulky feeds despite their adaptation to utilize such feeds. In effect, ruminants could hardly meet their nutrient requirements from such types of feeds. There was no significant $(\mathrm{P}>0.05)$ difference in feed conversion efficiency (FCE) among the concentrate fed groups. The high mean daily body weight gain of the goats on concentrate-supplements was in agreement with the findings of Galal and Kassahun (1981) in local highland goats supplemented with concentrates. The higher daily gains of concentrate-supplemented goats at the daily energy intake levels ranging from 4.02 to $5.30 \mathrm{MJ}$ ME per animal revealed that the goats of this particular breed might require less energy for maintenance than the recommended for different breeds of goats. On the other hand, increasing the concentrate level in the diet resulted in a significant $(\mathrm{P}<0.05)$ improvement in daily live weight gain in this study, which was 
comparable to the values reported for local Mid-Rift Valley and Somali goats (Getahun, 2001). However, correlation and regression analysis revealed a nonsignificant $(\mathrm{P}>0.05)$ weak negative association $(r=-$ 0.16 ) between ADWG and the level of concentrate supplementation.

\subsection{Carcass yield}

The carcass yield of goats as measured by the average values of rib-eye muscle area was superior for concentrate-supplemented groups (Table 3 ).

Table 3. Effects of feeding different hay to concentrate ratios on some slaughter traits in yearling intact Hararghe Highland goats

\begin{tabular}{|c|c|c|c|c|c|c|}
\hline \multirow[t]{2}{*}{ Slaughter traits } & \multicolumn{5}{|c|}{ Treatments } & \multirow[t]{2}{*}{ SEM } \\
\hline & $\mathrm{T} 1$ & $\mathrm{~T} 2$ & T3 & $\mathrm{T} 4$ & T5 & \\
\hline SW (kg) & $17.55^{\mathrm{c}}$ & $21.00^{b}$ & $20.20^{\mathrm{b}}$ & $21.80^{\mathrm{ab}}$ & $23.20^{\mathrm{a}}$ & 0.600 \\
\hline EBW (kg) & $12.78^{\mathrm{d}}$ & $17.00^{\mathrm{bc}}$ & $16.76^{\mathrm{c}}$ & $18.48^{\mathrm{ab}}$ & $19.83^{\mathrm{a}}$ & 0.510 \\
\hline HCW (kg) & $6.65^{c}$ & $9.60^{\mathrm{b}}$ & $9.55^{\mathrm{b}}$ & $10.20^{\mathrm{ab}}$ & $10.85^{\mathrm{a}}$ & 0.328 \\
\hline DPSW & $37.79^{\mathrm{b}}$ & $45.82^{\mathrm{a}}$ & $47.30^{\mathrm{a}}$ & $46.70^{\mathrm{a}}$ & $46.70^{\mathrm{a}}$ & 0.840 \\
\hline DPEBW & $51.99^{\mathrm{b}}$ & $56.56^{\mathrm{a}}$ & $57.02^{\mathrm{a}}$ & $55.10^{\mathrm{a}}$ & $54.66^{\mathrm{a}}$ & 0.800 \\
\hline $\operatorname{REA}\left(\mathrm{cm}^{2}\right)$ & $5.20^{\mathrm{c}}$ & $7.60^{\mathrm{b}}$ & $7.58^{b}$ & $8.70^{\mathrm{a}}$ & $8.80^{\mathrm{a}}$ & 0.236 \\
\hline
\end{tabular}

The slaughter weight and empty body weight of goats in all the groups offered with concentrate supplements were significantly heavier $(\mathrm{P}<0.01)$ than the control group. Goats in T5 showed significantly higher empty body weight $(\mathrm{P}<0.01)$ and heavier hot carcass weight $(\mathrm{P}<0.05)$ compared with the other groups except those in T4. There was positive and significant $(\mathrm{P}<0.01)$ relationship between slaughter weight $(r=0.89)$ as well as hot carcass weight $(r=0.90)$ with the level of concentrate supplementation.

Goats supplemented with concentrates had significantly higher $(\mathrm{P}<0.01) \mathrm{DP}$ compared to those fed on hay alone, but the level of concentrate had no significant effect $(\mathrm{P}>0.05)$ on DP. The high $(\mathrm{P}<$ 0.05) DP of goats supplemented with concentrate mixtures as compared to those raised on hay only was in agreement to the findings of Warmington and Kirton (1990) who reported the effect of nutrition on DP through variation in weight of gut contents or variation in actual organ weights, but contradicted with the results of Misra and Prasad (1996), who reported similar DP for goats supplemented with concentrates and those fed with roughages only. The DP for concentrate-supplemented groups was higher than the values reported by Getahun (2001) for Somali $(41.34 \%)$ and Mid-Rift Valley $(41.79 \%)$ goats raised on concentrate-based diets. Dressing percentages of 45.5, 43.5, 45.4 and 45.2 were recorded for Afar, Long eared Somali, Arsi-Bale and Woyto-Guji goats, respectively (Addisu, 2001), which were relatively lower than the values recorded for the concentrate fed groups in the present study. On the other hand, DP as high as 56.2-62.9\% in local Somali goats fed on a high plane of nutrition had been reported (Girma, 2000). The variations in DP reported in the present study and other similar experiments might be related with the differences in the breed of goats and in the plane of nutrition. Correlation and regression analysis revealed a positive and significant $(\mathrm{P}<0.01)$ relationship between DP and the level of concentrate supplementation $(\mathrm{r}=0.70)$.

Goats receiving concentrate had a significantly larger $(\mathrm{P}<0.01)$ rib-eye muscle area than those not offered concentrate, confirming the fact that goats on high plane of nutrition produced carcass with larger proportion of lean meat and deposited less fat in the carcass. According to Ashbrook (1955), the rib-eye muscle area gives an indirect estimate of body musculature and the ability of animals to put relatively more flesh on the rib-eye muscle area. Moreover, goats in T4 and T5 had significantly larger $(\mathrm{P}<0.01)$ rib-eye muscle area than the animals in the remaining groups. The values of rib-eye muscle area in concentratesupplemented groups were superior to the values of 6.5 $\mathrm{cm}^{2}$ for fattened and $4.03 \mathrm{~cm}^{2}$ for un-fattened yearling Sudan desert entire male goats (Gaili et al., 1972). There was positive and significant $(\mathrm{P}<0.01)$ relationship between the rib-eye muscle area $(\mathrm{r}=0.92)$ and the level of concentrate supplementation. 


\subsection{Carcass Tissue Components}

The weight of the left half cold carcass was heavier in goats fed equal proportions of hay and grass (T5) compared to those in T1, T2 and T3 (Table 4).

The weight of forequarter, hindquarter and lean were significantly $(\mathrm{P}<0.01)$ higher from the goats offered with concentrate compared to those fed with hay only. Goats in T5 yielded higher $(\mathrm{P}<0.01)$ lean meat than the animals in T1, T2 and T3, while goats in T2, T3 and $\mathrm{T} 4$ also produced more $(\mathrm{P}<0.05)$ amounts of lean tissue than those in T1. Similarly, carcasses from goats supplemented with concentrate produced higher percentage of lean $(\mathrm{P}<0.05)$, but carcasses from goats in T2, T3 and T4; T4 and T5 contained the same (P > 0.05) percentage of lean. Correlation and regression analysis revealed also a positive and significant $(\mathrm{P}<$ $0.01)$ relationship between the lean meat $(\mathrm{r}=0.95)$ and the level of concentrate supplementation.

Table 4. Effects of feeding different hay to concentrate ratios on left half-carcass tissue components in yearling intact Hararghe Highland goats

\begin{tabular}{|c|c|c|c|c|c|c|}
\hline \multirow[t]{2}{*}{ Tissue components } & \multicolumn{5}{|c|}{ Treatments } & \multirow[t]{2}{*}{ SEM } \\
\hline & $\mathrm{T} 1$ & $\mathrm{~T} 2$ & T3 & $\mathrm{T} 4$ & T5 & \\
\hline Left half (kg) & $3.50^{\mathrm{c}}$ & $4.70^{b}$ & $4.80^{\mathrm{b}}$ & $5.15^{\mathrm{ab}}$ & $5.45^{\mathrm{a}}$ & 0.170 \\
\hline Forequarter (kg) & $1.95^{\mathrm{c}}$ & $2.70^{\mathrm{b}}$ & $2.68^{\mathrm{b}}$ & $2.87^{\mathrm{b}}$ & $3.35^{\mathrm{a}}$ & 0.156 \\
\hline Hindquarter (kg) & $1.55^{\mathrm{b}}$ & $2.05^{\mathrm{a}}$ & $2.12^{\mathrm{a}}$ & $2.22^{\mathrm{a}}$ & $2.15^{\mathrm{a}}$ & 0.071 \\
\hline Lean $(\mathrm{kg})$ & $2.28^{\mathrm{c}}$ & $3.29^{\mathrm{b}}$ & $3.28^{\mathrm{b}}$ & $3.64^{\mathrm{ab}}$ & $4.07^{\mathrm{a}}$ & 0.158 \\
\hline Lean $(\%)$ & $64.90^{\mathrm{c}}$ & $70.04^{\mathrm{b}}$ & $68.54^{\mathrm{b}}$ & $70.67^{\mathrm{ab}}$ & $74.50^{\mathrm{a}}$ & 1.453 \\
\hline Bone (g) & $848.40^{\mathrm{a}}$ & $901.80^{\mathrm{a}}$ & $964.2^{\mathrm{a}}$ & $892.00^{\mathrm{a}}$ & $918.80^{\mathrm{a}}$ & 44.838 \\
\hline Bone $(\%)$ & $24.43^{\mathrm{a}}$ & $19.28^{\mathrm{bc}}$ & $20.06^{\mathrm{b}}$ & $17.32^{\mathrm{bc}}$ & $16.94^{\mathrm{c}}$ & 1.020 \\
\hline Fat $(\mathrm{g})$ & $374.20^{\mathrm{b}}$ & $509.20^{\mathrm{a}}$ & $531.8^{\mathrm{a}}$ & $567.40^{\mathrm{a}}$ & $573.40^{\mathrm{a}}$ & 37.144 \\
\hline Fat $(\%)$ & $10.77^{\mathrm{a}}$ & $10.78^{\mathrm{a}}$ & $11.09^{\mathrm{a}}$ & $11.09^{\mathrm{a}}$ & $10.55^{\mathrm{a}}$ & 0.860 \\
\hline Boneless meat (kg) & $2.65^{\mathrm{c}}$ & $3.80^{\mathrm{b}}$ & $3.82^{\mathrm{b}}$ & $4.20^{\mathrm{ab}}$ & $4.64^{\mathrm{a}}$ & 0.163 \\
\hline Boneless meat $(\%)$ & $75.67^{\mathrm{c}}$ & $80.82^{\mathrm{ab}}$ & $79.63^{\mathrm{b}}$ & $81.76^{\mathrm{ab}}$ & $85.06^{\mathrm{a}}$ & 1.540 \\
\hline Fat: lean & $0.17^{\mathrm{a}}$ & $0.15^{\mathrm{a}}$ & $0.16^{\mathrm{a}}$ & $0.16^{\mathrm{a}}$ & $0.14^{\mathrm{a}}$ & 0.014 \\
\hline Lean: bone & $2.70^{\mathrm{c}}$ & $3.67^{\mathrm{b}}$ & $3.51^{\mathrm{b}}$ & $4.09^{\mathrm{ab}}$ & $4.41^{\mathrm{a}}$ & 0.231 \\
\hline Fat: bone & $0.45^{\mathrm{a}}$ & $0.57^{\mathrm{a}}$ & $0.56^{\mathrm{a}}$ & $0.64^{\mathrm{a}}$ & $0.62^{\mathrm{a}}$ & 0.047 \\
\hline Lean + fat: bone & $3.14^{\mathrm{c}}$ & $4.24^{\mathrm{b}}$ & $4.06^{\mathrm{b}}$ & $4.73^{\mathrm{ab}}$ & $5.03^{\mathrm{a}}$ & 0.253 \\
\hline
\end{tabular}

Devendra and Owen (1983) observed that lean carcass composition of goats to be about $60 \%$, although relatively higher values of $63.6 \%$ in Iraqi black goats (Tahir et al., 1994) and 68.2\% in Omani Batina goats (Mahgoub and Lodge, 1996) had been reported. Exceptionally lower lean meat values of 55.3 and $59 \%$ had also been recorded in local Somali and Mid-Rift Valley goats, respectively (Getahun, 2001).

No significant $(\mathrm{P}>0.05)$ effect of plane of nutrition was observed on the weight of bone jointed from the carcass. However, the percentage of bone was higher $(\mathrm{P}<0.01)$ for goats in $\mathrm{T} 1$ as compared to carcasses from the other groups. Goats fed with concentrates had higher $(\mathrm{P}<0.05)$ lean: bone and lean + fat: bone ratios compared to those fed with hay only, whereas goats in T2, T3 and T4 groups and T4 and T5 groups had nearly equal $(\mathrm{P}>0.05)$ lean: bone and fat + lean: bone ratios.
The percentage of bone in the present study was lower than that of Somali (31\%) and Mid-Rift Valley (30.2\%) goats (Getahun, 2001), but higher than the values reported by Mahgoub and Lodge (1996) for Omani Batina goats (13.9\%). Carcass evaluation study by Ruvuna et al. (1992) showed $18 \%$ bone from 14.7 months old intact crossbred male goats. Warmington and Kirton (1990) noted an average bone percentage of 21.7 from eight goat breeds. Both of these reports are in agreement with the present finding. However, carcass composition of $34.2 \%$ bone was also recorded in Iraqi black goats (Tahir et al., 1994), which is higher than the present finding.

The weight of fat was significantly $(\mathrm{P}<0.05)$ lower in T1 when compared to the concentrate-supplemented groups. The level of concentrate-supplement had no effect $(\mathrm{P}>0.05)$ on $\%$ fat content, confirming the fact 
that goats have less potential to deposit fat in the carcass. The carcass fat percentage in this study was higher than the value $(9.3 \%)$ reported by Warmington and Kirton (1990), but lower fat percentage of 2.1 were noted in Iraqi black goats (Tahir et al., 1994). Unlike the percentage of boneless meat, the fat percentage was significantly lower $(\mathrm{P}<0.05)$ for goats fed with hay only compared with those fed with concentrate.

\subsection{Edible Offal Components}

Plane of nutrition resulted in a significant $(\mathrm{P}<0.05)$ effect on most of the edible offal components. Kidney fat and omental fat of goats offered with concentrate supplements were heavier $(\mathrm{P}<0.01)$ than those from goats in T1 (Table 5).

Table 5. Effects of feeding different hay to concentrate ratios on edible offal components in yearling intact Hararghe Highland goats

\begin{tabular}{|c|c|c|c|c|c|c|}
\hline \multirow[t]{2}{*}{ Components } & \multicolumn{5}{|c|}{ Treatments } & \multirow[t]{2}{*}{ SEM } \\
\hline & $\mathrm{T} 1$ & $\mathrm{~T} 2$ & T3 & $\mathrm{T} 4$ & T5 & \\
\hline Kidney fat (g) & $49.72^{b}$ & $125.60^{\mathrm{a}}$ & $150.40^{\mathrm{a}}$ & $153.60^{\mathrm{a}}$ & $150.00^{\mathrm{a}}$ & 11.397 \\
\hline Omental fat $(\mathrm{g})$ & $79.20^{\mathrm{d}}$ & $144.50^{\mathrm{c}}$ & $207.60^{\mathrm{b}}$ & $207.80^{\mathrm{b}}$ & $237.60^{\mathrm{a}}$ & 8.288 \\
\hline Intestinal fat (g) & $98.12^{\mathrm{c}}$ & $105.60^{\mathrm{bc}}$ & $127.60^{\mathrm{ab}}$ & $127.90^{\mathrm{ab}}$ & $153.50^{\mathrm{a}}$ & 9.165 \\
\hline Total visceral fat (g) & $227.00^{\mathrm{c}}$ & $375.70^{\mathrm{b}}$ & $485.60^{\mathrm{a}}$ & $489.30^{\mathrm{a}}$ & $541.10^{\mathrm{a}}$ & 20.340 \\
\hline Blood $(\mathrm{g})$ & $550.80^{\mathrm{a}}$ & $717.20^{\mathrm{a}}$ & $718.40^{\mathrm{a}}$ & $776.40^{\mathrm{a}}$ & $790.80^{\mathrm{a}}$ & 57.190 \\
\hline Kidneys (g) & $49.90^{\mathrm{c}}$ & $56.70^{\mathrm{b}}$ & $59.20^{\mathrm{b}}$ & $69.02^{\mathrm{a}}$ & $66.20^{\mathrm{a}}$ & 1.807 \\
\hline Liver (g) & $217.60^{\mathrm{b}}$ & $284.50^{\mathrm{ab}}$ & $365.60^{\mathrm{a}}$ & $333.04^{\mathrm{a}}$ & $377.08^{\mathrm{a}}$ & 31.251 \\
\hline Lungs (g) & $139.90^{\mathrm{b}}$ & $163.08^{\mathrm{a}}$ & $158.40^{\mathrm{ab}}$ & $169.72^{\mathrm{a}}$ & $178.12^{\mathrm{a}}$ & 6.730 \\
\hline Heart (g) & $63.84^{\mathrm{b}}$ & $82.12^{\mathrm{a}}$ & $84.80^{\mathrm{a}}$ & $81.74^{\mathrm{a}}$ & $94.48^{\mathrm{a}}$ & 5.167 \\
\hline Testicles (g) & $77.20^{\mathrm{c}}$ & $174.38^{\mathrm{ab}}$ & $140.40^{\mathrm{b}}$ & $200.3^{\mathrm{a}}$ & $185.20^{\mathrm{ab}}$ & 17.000 \\
\hline Ret-rum. (g) & $444.68^{\mathrm{a}}$ & $463.6^{\mathrm{a}}$ & $369.06^{\mathrm{a}}$ & $419.32^{\mathrm{a}}$ & $446.40^{\mathrm{a}}$ & 33.381 \\
\hline Oma-abom. (g) & $147.38^{\mathrm{a}}$ & $144.4^{\mathrm{a}}$ & $128.94^{\mathrm{a}}$ & $137.26^{\mathrm{a}}$ & $134.00^{\mathrm{a}}$ & 7.770 \\
\hline Small intestine (g) & $293.28^{\mathrm{b}}$ & $362.8^{\mathrm{a}}$ & $388.4^{\mathrm{a}}$ & $388.5^{\mathrm{a}}$ & $394.58^{\mathrm{a}}$ & 20.381 \\
\hline Total EO $(\mathrm{kg})$ & $2.212^{\mathrm{c}}$ & $2.824^{b}$ & $2.899^{\mathrm{ab}}$ & $3.059^{\mathrm{ab}}$ & $3.208^{\mathrm{a}}$ & 0.115 \\
\hline Total EO (\%) & $12.63^{\mathrm{a}}$ & $13.46^{\mathrm{a}}$ & $14.38^{\mathrm{a}}$ & $14.08^{\mathrm{a}}$ & $13.78^{\mathrm{a}}$ & 0.426 \\
\hline Total edible $(\%)$ & $50.42^{\mathrm{c}}$ & $56.85^{\mathrm{b}}$ & $62.15^{\mathrm{a}}$ & $60.78^{\mathrm{a}}$ & $60.51^{\mathrm{ab}}$ & 0.928 \\
\hline
\end{tabular}

All the concentrate-supplemented groups produced nearly equal amount $(\mathrm{P}>0.05)$ of kidney fat, but goats in T5 produced higher $(\mathrm{P}<0.05)$ omental fat than those in T2, T3 and T4. Moreover, goats receiving the concentrate diet, except at $20 \%$ concentrate level, produced significantly higher $(\mathrm{P}<0.05)$ intestinal fat than the animals in $\mathrm{T} 1$ though no differences $(\mathrm{P}>0.05)$ were observed among those in T3, T4 and T5; and T2, T3 and T4. Goats in T3, T4 and T5 produced higher (P $<0.01$ ) visceral fat (intestinal fat + kidney fat + omental fat) compared to those in T1 and T2. The results of this study substantiated the common understanding that goats deposit visceral fat when offered feeds that promote fat deposition.

The weights of blood, reticulo-rumen, omasoabomasum and percentage of total edible offal components of the different groups did not differ $(\mathrm{P}>$ 0.05), whereas the weights of kidneys, heart, testicles, small intestine and total edible offal components were significantly higher $(\mathrm{P}<0.05)$ in concentratesupplemented groups than those raised on hay only.

In agreement with the present finding, Almedia et al. (2000) pointed out that under-nutrition created a detrimental effect on the weights of heart, liver and most of the carcass portions in young Boer goats. Considering the weight of total edible offal components, goats raised on concentrates were found to be superior $(\mathrm{P}<0.05)$ to the goats raised only on hay. Increasing concentrate level resulted in an increase in the weight of total edible offal components, but no significant $(\mathrm{P}>0.05)$ differences were observed between T2, T3 and T4 as well as between T3, T4 and T5. Addisu (2001) reported edible offal components of 15 and $16.5 \%$ for local Arsi-Bali and Afar goats in Ethiopia. Similarly, Verma et al. (1996) reported 16.2 to $17.1 \%$ edible offal components on slaughter weight basis for local goat breeds in India.

The disparities in the edible offal percentages in different findings might be partly due to differences in 
inclusion of individual offal in the edible proportion. For instance Verma et al. (1996) considered head and feet as edible offal components, which were considered as inedible in the present study. Accordingly, in comparing different findings of offal components all the parts considered, as edible should be clearly mentioned. The proportion of total edible components (carcass + edible offal) in this study was similar to the values reported for local Somali and Mid-Rift Valley goats supplemented with concentrates (Getahun, 2001). 3.5. Non-edible Offal Components

Goats offered with hay only had higher $(\mathrm{P}<0.05)$ weights or percentages of gut contents and percentage of total non-edible offal components than the goats supplemented with concentrate (Table 6).

Table 6. Effects of feeding different hay to concentrate ratios on non-edible offal components in yearling intact Hararghe Highland goats

\begin{tabular}{|c|c|c|c|c|c|c|}
\hline \multirow[t]{2}{*}{ Components } & \multicolumn{5}{|c|}{ Treatments } & \multirow[t]{2}{*}{ SEM } \\
\hline & $\mathrm{T} 1$ & $\mathrm{~T} 2$ & T3 & $\mathrm{T} 4$ & T5 & \\
\hline Spleen $(\mathrm{g})$ & $16.84^{\mathrm{c}}$ & $26.36^{\mathrm{b}}$ & $32.4^{\mathrm{ab}}$ & $33.48^{\mathrm{ab}}$ & $36.8^{\mathrm{a}}$ & 2.850 \\
\hline RR-OA content $(\mathrm{kg})$ & $3.921^{\mathrm{a}}$ & $3.342^{\mathrm{ab}}$ & $2.848^{\mathrm{bc}}$ & $2.552^{\mathrm{c}}$ & $2.740^{\mathrm{bc}}$ & 0.204 \\
\hline Large intestine (g) & $208.74^{\mathrm{b}}$ & $219.2^{\mathrm{b}}$ & $214.04^{\mathrm{b}}$ & $281.64^{\mathrm{a}}$ & $289.2^{\mathrm{a}}$ & 15.096 \\
\hline Gut content (kg) & $4.774^{\mathrm{a}}$ & $3.998^{\mathrm{b}}$ & $3.437^{\mathrm{bc}}$ & $3.318^{\mathrm{c}}$ & $3.369^{\mathrm{bc}}$ & 0.218 \\
\hline Gut content $(\%)$ & $27.34^{\mathrm{a}}$ & $18.98^{\mathrm{b}}$ & $17.02^{\mathrm{bc}}$ & $15.30^{\mathrm{c}}$ & $14.49^{\mathrm{c}}$ & 0.855 \\
\hline Skin $(k g)$ & $1.133^{\mathrm{c}}$ & $1.722^{\mathrm{b}}$ & $1.715^{\mathrm{b}}$ & $1.748^{\mathrm{b}}$ & $2.089^{\mathrm{a}}$ & 0.081 \\
\hline Feet $(\mathrm{g})$ & $482.8^{\mathrm{a}}$ & $510.4^{\mathrm{a}}$ & $508.00^{\mathrm{a}}$ & $497.2^{\mathrm{a}}$ & $523.60^{\mathrm{a}}$ & 13.420 \\
\hline Tail (g) & $24.4^{\mathrm{a}}$ & $28.54^{\mathrm{a}}$ & $29.60^{\mathrm{a}}$ & $34.4^{\mathrm{a}}$ & $30.00^{\mathrm{a}}$ & 2.330 \\
\hline Total NEO (kg) & $8.046^{\mathrm{a}}$ & $8.147^{\mathrm{a}}$ & $7.564^{\mathrm{a}}$ & $7.846^{\mathrm{a}}$ & $8.169^{\mathrm{a}}$ & 0.267 \\
\hline Total NEO (\%) & $45.98^{\mathrm{a}}$ & $38.74^{\mathrm{b}}$ & $37.52^{\mathrm{bc}}$ & $36.18^{\mathrm{bc}}$ & $35.25^{\mathrm{c}}$ & 0.950 \\
\hline
\end{tabular}

On the other hand, the weights of skin and spleen were significantly $(\mathrm{P}<0.05)$ lower in goats fed only on hay. Unlike the gut content and percentage of total nonedible offal components, the weight of spleen increased as the concentrate level increased even if no significant differences $(\mathrm{P}>0.05)$ were recorded among T2, T3 and T4; T3, T4 and T5. The weight of feet, tail and total non-edible offal components were the same $(\mathrm{P}>0.05)$ irrespective of the concentrate proportion.

The decreasing trend of gut content with increasing concentrate level might be attributed to the relatively higher rate of digestion and faster passage rate of the diet through the tract (Misra and Prasad, 1996). In agreement with the present finding, Gaili et al. (1972) concluded that the gut content (digestive tract) as a proportion of live weight decreased significantly in goats fed with high quality diet. Hatendi et al. (1990) reported gut content varying from 10 to $23 \%$ of live weight in Botswana goats; recently Getahun (2001) also reported 18.5 and $15 \%$ gut contents in local Somali and Mid-Rift Valley goats, respectively.

\section{Conclusions}

Concentrate supplementation up to the level of $50 \%$ of the total diet did not result in improved DM intake( $\mathrm{g} / \mathrm{kg} \mathrm{MBW}$ and \%BW) but increased nutrient intake and daily body weight gain of yearling intact Hararghe Highland male goats. Concentrate supplementation improved carcass yield characteristics as measured by slaughter weight, empty body weight, hot carcass weight, dressing percentage and rib-eye muscle area, edible and non-edible offal components and yielded carcasses having higher percentages of lean and boneless meat, but lower percentage of bone as compared to goats fed on grass hay alone. Supplementation did not have a significant effect on the percentage of carcass fat, fat: lean and fat: bone ratios, but resulted in higher lean: bone and lean + fat: bone ratios than those fed hay alone. Supplementation of yearling Hararghe Highland goats with different hay to concentrate ratios produced also higher weights of visceral fat but the percentage of total edible offal components was not affected. The gut content and total non-edible offal components decreased with the increasing the concentrate level. Correlation and regression analysis revealed a positive and significant $(\mathrm{P}<0.01)$ relationship between dry matter intake $(\mathrm{r}=$ $0.67)$, slaughter weight $(r=0.89)$, hot carcass weight $(r$ $=0.90)$, dressing percentage $(r=0.70)$, lean meat $(r=$ $0.95)$ and rib-eye muscle area $(r=0.92)$ with the level 
of concentrate supplementation. However, there was a non-significant $(\mathrm{P}>0.05)$ weak negative correlation $(\mathrm{r}=-0.16)$ between ADWG and the level of concentrate supplementation. Considering the fact that the concentrate supplementation levels did not result in the improvement of anyone of the parameters studied, the diet with $20 \%$ concentrate level could be considered as economically feasible and affordable level of supplement for the majority of the smallholder farms in the diets of yearling intact Hararghe Highland goats.

\section{Acknowledgements}

The authors thank the Agricultural, Technical, Vocational, Education and Training Project of Ministry of Agriculture for funding and Haramaya University for research facilities.

\section{References}

Addisu, A. 2001. A comparative study on slaughter components with emphasis on edible offal of some indigenous goat types. MSc Thesis. Alemaya University, Alemaya, Ethiopia. 94 p.

Almedia, A.M., Schwalbach, L.M., Cardoso, L.A. and Greyling, J.P.C.. 2000. The effect of undernutrition on carcass characteristics in young Boer goat bucks. International Conference on goats, 15-21 May 2000, France. p. 668.

AOAC (Association of Official Analytical Chemists). 1990. Official Methods of Analysis, $15^{\text {th }}$ ed. Association of Official Analytical Chemists, Washington DC.

ARC (Agricultural Research Council). 1980. The Nutrient Requirement of Ruminant Livestock. Common Wealth Agricultural Bureaux, Slough, England.

Ashbrook, F.G., 1955. Butchering, Processing and Preservation of Meat. D-Van Nostrand Company, Inc., London. pp.105-151.

Aschalew, T., Sisay, L., Ameha, S., Abebe, M. and Zinash, S., 2000. National goat research strategy in Ethiopia. In: Merkel, R.C., Girma Abebe and Goetsch A.L, (eds.). The opportunities and challenges of enhancing goat production in East Africa. 10-12 November 2000, Debub University, Awassa, Ethiopia. pp.1-5.

AUA (Alemaya University of Agriculture). 1996. Proceeding of the $13^{\text {th }}$ annual research and extension review meeting, Alemaya University of Agriculture, February 26-28, 1996, Alemaya, Ethiopia.

CSA (Central Statistical Authority). 2003. Agricultural sample survey statistical bulletin, Addis Ababa, Ethiopia.
Devendra, C. and Burns, M. 1983. Goat Production in the Tropics. $2^{\text {nd }}$ edition. Commonwealth Agricultural Bureaux, UK. P.56.

Devendra, C. and Owen, J.E. 1983. Quantitative and qualitative aspects of meat production from goats. World Animal Review 47:19-29.

FAO (Food and Agricultural Organization), 1997. Tree Foliage in Ruminant Nutrition. FAO Animal Production and Health Paper 139. FAO, Rome, Italy. p. 2.

FAO (Food and Agricultural Organization). 2001. Production yearbook. Vol. 55. FAO, Rome, Italy.

Galal, E.S.E. and Kassahun, A. 1981. The effect of roughage-concentrate ratio on fattening performance in goat kids. In: Nutrition and systems of goat feeding symposium. Tours, France, 12-15 May 1981, pp. 363-368.

Gaili,, E.S.E., Ghanem, Y.S. and Mukhtar, A.M.S.1972. A comparative study of some carcass characteristics of Sudan Desert sheep and goats. Animal Production 14:351-357.

Getahun, L. 2001. Growth pattern and carcass characteristics of Somali and Mid-Rift Valley goats. MSc thesis. Alemaya University, Alemaya, Ethiopia. 123 p.

Girma, A. 2000. Carcass characteristics of Somali goats slaughtered at different ages. In: Seventh International Conference on goats, 15-21 May 2000, France. p.829

Hatendi, P.R., Smith, T., Ndlovu, L. and Mutisi, C. 1990. Fattening mature indigenous (Matabele) goats: Effects on animal performance, body and carcass composition. In: Proceedings of the first Biennial Conference of the African Small Ruminant Research Network, Nairobi, Kenya, 10-14 December 1990, ILCA, Kenya. pp. 355-365.

Mahgoub, O. and Lodge, G.A. 1996. Growth and body composition in meat production of Omani Batina goats. Small Ruminant Research 19(3): 233-246.

Manfredini, M., Massari, M., Cavani, C. and Falaschini, F. 1988. Carcass characteristics of male Alpine kids slaughtered at different weights. Small Ruminant Research 1:49-58.

McDonald, P., Edwards, R.A., Greenhalgh, J.F.D. and Morgan, C.A. 2002. Animal Nutrition. $6^{\text {th }}$ ed. Prentice Hall, London. pp. 471-581.

Menke, K.H. and Steingass, H. 1988. Estimation of the energetic value obtained from chemical analysis and in vitro gas production using rumen fluid. Animal Research Division 28: $7-$ 55.

Misra, R.K and Prasad, V.S.S. 1996. Studies on carcass characteristics of goats at different ages and 
feeding systems. Indian Veterinary Journal 73: $150-153$.

Ruvuna, F., Taylor, J.F., Okeyo, M., Wanyoike, M. and Ahuya, C. 1992. Effects of breed and castration on slaughter weight and carcass composition of goats. Small Ruminant Research 7: 175-183.

Parthasarathy, M., Singh, D. and Rawat, P.S. 1984. Performance of feedlot kids on different dietary regimen. Indian Journal of Animal Science 54 (1): 130-131.

Pralomkarn, W., Kochapakdee, S., Saithanoo, S. and Norton, B.W. 1995. Energy and protein utilization for maintenance and growth of Thai native and Anglo-Nubian x Thai native male weaner goats. Small Ruminant Research 16(1): 13-20.

SAS. 1998.Version 7. Guide to personal computers. Cary, NC: Statistical Analysis Systems Institute.

Shahjalal, M., Galbraith, H. and Topps, J.H. 1992. The effect of changes in dietary protein and energy on growth, body composition and mohair fibre characteristics of British Angora goats. Animal Production 54:405-412.

Tahir, M.A., Al-Jassim, A.F. and Abdulla, A.H.H. 1994. Influence of live weight and castration on distribution of meat, fat and bone in the carcass of goats. Small Ruminant Research 14(3): 219-223.

Van Soest, P.J., Robertson, J.B. and Lewis, B.A. 1991. Methods for Dietary Neutral Detergent Fiber and Non-starch Polysaccharides in Relation to Animal Nutrition. Journal of Dairy Science 74: 3583-3597.

Verma, A.K., Sastry, V.R.B. and Agrawal, O.K. 1996. Chevon characteristics of goats fed diets with water washed neem (Azadirachta indica) seed kernel cake. Small Ruminant Research 19 (1): 55-61.

Warmington, B.G. and Kirton, A.H. 1990. Genetic and non-genetic influences on growth and carcass traits of goats. Small Ruminant Research 3: $147-165$. 